\title{
SPACE FOR PEOPLE IN A CONTEMPORARY CITY - WHAT ARCHITECTURAL AND TOWN PLANNING SOLUTIONS HELP IN SHAPING A FUNCTIONAL AND CONVENIENT STREET?
}

\begin{abstract}
One of the basic ingredients of the city tissue are streets. Closely related to the buildings, they defined the pattern of the tissue, or constituted its derivative. The street has always been an important element shaping the character of a city. It played not only the role of transport, but also served as a place for meetings and trade exchange. According to the contemporary urban planning trends, while designing building complexes one should employ an interdisciplinary approach. Apart from classical engineering one should also use the achievements of sociology and psychology. Besides the proportions of a horizontal surface, the architectural solutions of buildings in a street have the most significant influence on the way that a street is perceived by its users. The examples of guidelines on shaping the right space of a street are as follows: the right height of buildings, their location relative to the street or the right arrangement of window and door openings. The purpose of the article is to introduce and compile the sources describing the urban planning and architectural guidelines that influence the creation of a people-friendly street. The analyzed texts concern both architectural solutions and issues from the field of psychology of space.
\end{abstract}

Keywords: public places, street design, urban planning and architectural guidelines, psychology of space

A city is a complex spatial and functional structure. The transport layout with the network of streets and squares constitutes its basic component. Wojciech Wicher, in his doctoral thesis "The Studies in Typology of a Street As an Element of Urban Analysis" attempts to define what a street is. The first definition refers to its formal and legal status:

„A street is a strap of land legally delineated by lines, designated for traffic or stopping of vehicles, as well as for pedestrian traffic, and what is more, for constructing engineering fittings." [8]

\footnotetext{
${ }^{1}$ Joanna Dudek, Rzeszow University of Technology, Faculty of Civil and Environmental Engineering and Architecture, al. Powstańców Warszawy 12,35-959 Rzeszów, Poland, jdudek@prz.edu.pl
} 
The author considers that definition incomplete and thus quotes another one describing the function of a street as an element crystallizing the urban planning composition:

"In the spatial sense, a street is comprised of its buildings that, through their scale, typology and functions residing in them, shape the character of a street as the urban planning interior."

Furthermore, the author emphasizes the sociological phenomenon of a street:

"A street is the total of social activity centered inside a space defined by the surrounding buildings and generated by their inherent functions." [8]

Therefore, the role of a street network in a city is very complex. The aim of a road designer, urban planner and architect is to design streets that will simultaneously perform their transporting function and be an efficient public space. It is important that these two aspects are taken into account as equally significant during the designing process. Only then is there a chance of developing a city in a balanced and equable way. It should be noted that achieving such balance is possible through the right organization of city transport and through elimination of transit traffic from the city centre and residential districts. A properly designed street is space where a lot of activities take place. Various human activities have direct influence on the development of trade and services, security level and real estates' value. But most of all, the way transport is organized has impact on the quality of human life. These actions may result in development, an increase in the attractiveness and the value of a city or a district. At the same time wrong decisions connected with designing may result in degradation of the area.

The contemporary designing trends respond to today's society's requirements and its current needs. Searching for guidelines on shaping a street as a modern public space, researchers also analyze the historical urban planning processes. The knowledge of positive solutions from the past helps to shape a street space for the future. City streets were built in various ways over the centuries. In this part of the article I shall refer to the historical periods that brought significant changes in the approach to creating a street in a city.

A loose form of the street layout was characteristic of the Middle Ages. Traffic routes were planned merely to the extent that was necessary for separating individual areas of usage and were adjusted to topographical conditions. First and foremost streets were supposed to be useful, therefore, their shape depended on the needs of inhabitants. They were usually narrow as they were used mainly for pedestrian traffic. The greatest number of examples of medieval cities with this limited layout that survived in almost unaltered form can be found in Italy and former Yugoslavia. In Poland the first instances of locating cities based on German law happened at the end of the thirteenth century. Cracow, Poznan and Lviv are examples of cities that assumed geometric layout at that time. 
The Renaissance developed a trend of designing cities with regular street layout. The appearance and the spatial effect of buildings created through the building development of a street were of the greatest importance to the designers of this historical period. Space between buildings was supposed to be optimally adjusted to transport and formal social functions such as marches and processions. Pamanova is the epitome of renaissance designing ideas - a city and a fortress in the north of Italy. In the main square Piazza Grande with surface area of 30000 square meters, which is believed to be too large for a city with surface area of 13 square kilometers, there meet streets of stellar layout. Each street regardless of location or function is 14 meters wide.

In the Enlightenment the wheeled transport develops more and more. It forces city authorities to properly regulate streets, improve the road surface and build pavements. A new model of a city is not created. Urban layouts are developed based on Renaissance models. Streets designed in this historical period were straight and wide. Planting shrubs and trees along routes was the origin of the new types of streets: avenues and boulevards.

Functionality brought a major change to the way that cities were shaped. Designers creating in accordance with this trend rejected contemporary urban planning solutions based on streets and squares. They were replaced with paths and roads as well as vast, spatially indeterminate lawns that were not defined by buildings. Buildings designed in a loose layout were supposed to provide inhabitants with hygienic conditions of life. Dark and stifling flats were replaced with bright and airy ones. Small, dim quarter tenement house yards were replaced with extensive green space. Today we know that solutions aiming at improving hygiene and inhabitants' comfort of living in buildings resulted in mitigation of social life and interaction. Distances between buildings created better living conditions but they generated space that hindered outdoor activity. Its significant decrease limited human relationships. Functionality required isolating areas of building development of a single function each. The rapid advancement of motorization favoured the separation of functions. The car changed they way that a street is used in a major way. The dominance of transport function increased the troublesomeness of traffic routes. An increase in noise and pollution was accompanied by a decrease in the safety of street usage. The need for greater safety of the inhabitants of adjoining buildings and pedestrians determined the necessity of greater distance between the lines of buildings and using additional road fittings. New guidelines had significant impact on designing cross sections of traffic routes. Partial or total separation of

the pedestrian traffic and car traffic was an attempt to solve the increasing conflict between the two.

The end of the twentieth century is the beginning of introducing new architectural and urban planning solutions based on tried-and-tested designing methods of the past adapted to contemporary reality. In many cities building 
development areas created based on functionality are given a second life. A street as an essential part of a city gains significance again.

In his book „A Street In The City Structure” Andrzej Gawilkowski writes:

"Functional specialization, which was precipitated by dynamic motorization advancement, led to distinguishing two types of streets. The first type is represented by traffic arteries serving almost exclusively transport and freight forwarding functions. The second type refers to other streets with various functions catering to the needs for a public space, a place for diverse human interactions. [...] Streets are elements of internal spatial structure of structural units delineated by (among other things) arteries.”[2]"

The author points out that the intensity of traffic and the speed of cars have influence on the character of a street. Depending on these factors a traffic route can be an integrating force or an oppressive barrier. Basically, a traffic artery that is a technical space should be as isolated as possible in order to eliminate any potential collisions. While "other street" as a public space should create conditions for users to interact. That is why it is so vital to aspire to tone down or decrease the presence of car traffic in the street space. Gawlikowski suggests that this goal can be achieved through reducing the number of traffic lanes and dedicating this space to cyclists and pedestrians, designating public transport a priority and limiting parking options. He also suggests delineating closed zones for road traffic. One should bear in mind, though, that a controlled number or a lack of cars in a street space will not automatically open a public space. It is, however, a base for further designing way.

Jan Gehl is an architect and a prominent expert in the area of shaping architecture and urban planning. He published his research on the influence of physical environment on the quality of open spaces in the book "Life Between Buildings". In the book, he attempts to provide a recipe for lively cities and names the factors that influence a public space in a positive way. A street is a public space and it must create the right conditions for various types of activities to take place. Gehl divides these activities into necessary, optional (recreational) and social. He defines them in the following way:

„Necessary activities are the ones that are more or less obligatory - going to school or work, doing shopping, waiting for a bus [...] - in other words all activities that people are required to do to a greater or lesser exent."'[3]

„Optional activities are those that happen if there is willingness, time and place for them to take place $[. .$.$] - a stroll to take a breath of fresh air, standing$ still to enjoy the beauty of a surrounding area, or sitting and sunbathing."[3]

,Social activity is a type of activity that depends on the presence of other people in public spaces. Social activities include children's play, greetings and conversations, various urban activities of people and finally - as the most common public behaviour - passive contacts that is simply watching and listening to other people.’'[3] 
A street is an attractive place if all the aforementioned activities appear to the same extent. It can be summarized through the following excerpt from Gehl's book:

"Any place that there are people [...] it is commonly accepted as true that people and their activity attract other people. People attract people. They gather and move with others, and they try to be close to others. New types of activity begin in the vicinity of other events that are already happening." [3]

Jan Gehl draws our attention to transport in the streets. He names the one that activates them the most. It is the pedestrian traffic. The author points out that there are few cities in Europe where pedestrian traffic is the basis for urban traffic. An example of such a city is Venice where the citizens move on foot, the cars remain outside the very centre, and goods are transported on water canals like they were centuries ago. Implementing these solutions in other cities is possible in their centres and in housing estates. If, however, there must be car traffic in a housing estate, it should be toned down as much as possible. In Dutch cities Woonerf type of streets are popularly designed where cars can approach the very door of a building. Cars travel there at a very low speed overtaking on their way components of the interior such as squares or playgrounds. In a way, they are guests in the pedestrians' domain. Gehl shows us the example of such city that is Delft, where a slowed down integrated traffic system was introduced in 1969 and has been considered to be exemplary ever since. Simple and safe, the system causes the multifunctional street space to stimulate various types of activity.

The proper conditions for moving in space are important, but even more so is placing varied functions in the street area in order to enable participation in the aforementioned activities. We should create such conditions that will generate a possibility for the users to stay outside houses and cars for as long as possible. The right shaping of architecture and urban planning has direct impact on the attractiveness of places. The author of "Life Between Buildings" provides triedand-tested designing guidelines. A selection of these guidelines will be presented in the article.

A traffic route should be defined by buildings. Preferably the buildings should be lined along a street, in a tight row, walls adjoining, which helps to avoid empty spaces between them that are difficult to adapt. The perfect examples of the aforementioned layout relative to a street are popular downtown tenement houses and terraced houses located outside the city centres. Activities between such buildings are not dispersed, they are accumulated and channeled due to such layout.

Gehl also emphasizes that, while the position of buildings relative to a street is important, the distance between a building and a street is also vital. Buildings, especially those with services on the ground floors, should not be located more than 15 meters away from a street. If the distance is greater than that, it is impossible for the observer to see what happens inside a place, he or she loses eye contact, and therefore does not feel encouraged to walk inside. For the same reasons, it is crucial that an elevation should be fitted with glass as much as 
possible. The lack of eye contact lowers the attractiveness of a place, decreasing the number of potential users in a given space.

An architect designing a street must minimize the presence of so-called „dead façades”. It means designing frontage in the style of shopping centres, locating as many entrances to buildings or service providers as possible in a short distance. Gehl suggests that the number of entrances should be between 15 and 25 units per 100 meters of façade. The authorities of some Danish cities successfully influence the functions present in some buildings. Counteracting the creation of ,dull” frontages, the local building law forbids placing functions such as offices and banks on the ground level. Other cities allow these functions on the ground floor of frontage with a limit of 5 meters length. This solution aims at maximizing the number of people moving along the façade.

Gehl encourages to make sure that all the functions of a street are on the same level. He suggests that all kinds of subways or overpasses and any means by which people disperse to different levels should be avoided. He argues that functions located horizontally even within 100 meters away from each other influence one another better than those located 3 meters above or below one another.

He also stresses that if it is possible, a so-called ,soft limit” between a public space and a private space should be designed. It could be a small garden in front of the entrance or a porch. It allows activity to happen, and it takes place on the inhabitant's property, but it actually happens in the street space.

Kevin Lynch, an American urban planner, the author of ,The Image of the City," believes that there are five elements that constitute the way observers perceive and gather information about a city. He defines them as edges, areas, hubs, landmarks and roads. He points out that traffic routes should be designed in a uniform and constant way in their entire length by means of characteristic forms of expression, in order for them to be a component of visual hierarchy of streets and city routes.

„The key routes should have certain special quality that sets them apart from surrounding traffic routes: centralization of some way of using or activity along its edges, characteristic property of a space, special texture of floor or façade, particular pattern of lighting, unique set of scents and sounds, a detail or a way of

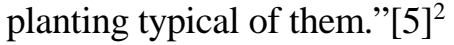

$\mathrm{He}$ also encourages to keep streets straight and their direction rather unchanged, explaining that a user likes to have a sense of destination. He or she likes to see it or feel they are approaching it. That is why the main traffic routes should be divided into shorter sections to create in a user a sense of sequence. It can be achieved through characteristic buildings, narrowings or space openings that appear rhythmically. One can use asymmetry in building development, slanting in land or a change in the character of greenery every now and then.

${ }^{2}$ Gehl J.: Life Between Buildings: Using Public Space, RAM, Cracow 2013, page 9,10,12 and 23 
Christopher Alexander points out that streets can be a kind of an urban theatre. Considered a prominent contemporary architecture theoretician, he writes in his book "A Pattern Language":

"Any subculture must have its centre for social life - a place where you can go to look at people and be seen oneself. [...] Streets should serve the purpose of spending time in them, and not merely to travel on them [...]". [1]

He describes how to create a space where diverse events can take place. A space that generates movement invites to live in it. Living space is characterized by the fact that for its every 15 to 30 square meters there is at least one person. Otherwise the areas seem dead. The author offers a few guidelines on how architecture should be shaped for it to encourage users to use the adjoining space.

Alexander describes the big influence that the height of buildings has on how a street is perceived:

"High buildings [...] do not help to create open spaces, they degrade the cityscape, ruin social life, increase crime, and make children's life harder. What is more, they are expensive to maintain, they have destructive impact on surrounding open areas, and they block light, air and views. [...] it has been established empirically that they have destructive influence on human psyche and feelings." [1].

He suggests that buildings should have a maximum of 4 storeys. For people who stay above the fourth storey the contact with what happens on the ground level diminishes significantly.

Below the fourth storey it is possible for people not only to observe but also to participate in the events that take place in the urban space. An inhabitant of a low building can easily see and hear what happens in a street. That is how he is a participant of the entire street scene.

Alexander recommends that housing buildings should not be one monolithic solid, but consist of smaller components or constitute complexes. Solids should be appropriately varied to reflect the usage by smaller social groups. In a solid of a building the windows should face a street. It is significant for the users to be able to observe life in the street. It is even more important that a building without windows facing a street causes fear in the pedestrians. These negative feelings may lead to avoiding the building. The services located on the ground level should be fitted with maximally large glass or even have sliding walls or roller-blinds. It should ensure that passers-by are interested in what happens inside buildings. The examples of functions successfully using this method are cafes, restaurants, openair food stalls, souvenir stalls or workshops. It is different when there are flats on the lowest storey. In such a situation it is inadvisable for passers-by to look inside the buildings. The windows of flats should then be on the ground level raised 60 to 90 centimeters above the ground surface. Another means of ensuring a sense of privacy for the inhabitants is placing window slots in an alcove raised relative to the rest of the interior in such a way that window sill is 1.5 meters above the ground. 
The author also draws our attention to the entrances to buildings. It is vital that they should be located in such a way that people approaching a building notice them as quickly as the building itself. Considering the fact that we often approach a building looking at it at a sharp angle, it is vital that the entrance is set apart from the entire solid in terms of shape. For example, it can be moved forward relative to the line of a building or emphasized by designing higher part of a building over the entrance. Additionally, it is worth enhancing an entrance using the right detail or a different colour in elevation.

Dividing a solid into smaller parts and enhancing entrances should improve the way a building is perceived by people, and therefore create the most pleasant space for staying and using that is possible to create.

The author points out how important in perceiving a street space is the shaping of its edge. It is this part of a street or square that social life centres around. People do not feel comfortable in the middle of an open area, and therefore it is beneficial if an edge of space is created in a way that encourages someone to stop. As Alexander claims, an edge of a street or square should be surrounded by: ,[...] Pockets of activities - small, partly closed areas next to an edge that protrude into an open area between pedestrian traffic routes $[\ldots]$ in a natural way encouraging passersby to stop." [1]

These could be niches, low walls to sit on, poles, arbors, gardens, benches or arcades.

The last of the listed elements is particularly worth discussing, according to Alexander. Even though arcades are an outer part of a building, they make an impression of a generally accessible interior. They integrate the building with space available to everyone. Moving along edges in the arcades of a building gives one a feeling of security, protects from rain and sunlight, and most of all offers one an opportunity to observe things in an interesting way. This observation allows one to notice the interior of a building and its details, as well as general events happening in a street or square. Arcades should be as low as possible and supported by wide pillars that one can lean against. Pillars should be enlarged with wide beams or arches to create a feeling of closure.

„What determines the artistic value of a complex is shaping all elements that constitute its three dimensions watched and experienced by man. These elements include a floor, walls and a ceiling. [...] Creating various pictures that will provide numerous experiences depends on the shaping of these elements," [7] writes Kazimierz Wejchert in his book „Elements of Urban Composition.” He shows that there are many factors that determine the perception of a street space that is one of the basic kinds of urban planning interior. He assigns the name the Ceiling of urban planning interior to the things that are found above the observer - the sky spread over the buildings and high greenery, the arcades of buildings, balconies, roofs and marquees. A Wall in the urban sense, according to Wejchert, comprises vertical surfaces delineated by buildings, high greenery and small architecture 
(statues, sculptures, fountains) or detached points of sale. While in the context of a street he draws special attention to its final element - the floor.

„A floor, in the urban planning sense, is the area that constitutes the base for the entire complex, visible in part or in its entirety that allows one to read and feel the vastness of an interior compared to the scale of man [...] An urban planning floor surrounded by buildings, which sometimes create a complex, plays a prominent part in creating the image of a space." [7]

It consists of the surfaces of green areas, water and hardened areas such as roadways, pavements, pedestrian routes and cycle lanes, squares and car parks.

A floor can also include elements of urban planning interior fittings such as seats, stairs, low walls, poles, bicycle racks, bins or low greenery under 1 meter high.

In the process of designing a harmonious interior shaping an urban planning floor gives one the greatest number of possibilities for using a detail directly influencing an observer. The design of the floor should complete the architecture of buildings. It is the designer who decides on colour and texture of a floor, the division of surfaces and the layout of their lines allowing optical adjustment of the width and length of a floor. The use of more refined materials allows the creation of more sublime space of distinct character. According to Katarzyna Pluta, the author of „Public Space of the European Cities,”

„Individually shaped material and technological solutions set apart such projects from many others. The originality of composition of premises that is achieved this way is the main factor influencing the creation of individual public space identity."[6]"

The originality of solutions favours recognizability of a given public space in the context of an entire city, but also gives them unique identity. Spaces that are characteristic, interesting and create absorbing picture of an interior encourage one to stay in them. Pluta believes that an equally vital designing task is to ensure that every user (especially the elderly and the handicapped) is provided with equal access to a public space that is a street. According to her

„The main barriers [...] include: pavement irregularities, a lack of colour and texture marking of vertical and horizontal elements of small architecture and a lack of limiting them with curbs or bands with different colour or texture of the surface, $[\ldots]$ too high curbs, a lack of ramps, [...] slippery surfaces, a lack of parking spaces, a lack of pedestrian crossings in the vicinity of a building."[6]

The task of a designer is to ensure complete accessibility to all parts of a street and eliminate all barriers that reduce the comfort of its usage.

All the creators of guidelines that are quoted in the present article had one essential goal. It was to define universal rules that should characterize a design of a new street. In terms of civilization we strive to improve the things around us, the vehicles that we travel by, rooms where we live and work. We continually increase their ergonomics, the pleasure of usage, and the safety of operating. We enhance their esthetic advantages, appreciate the modern pattern, and we often go 
back to using tried-and-tested solutions from the past. The modern urban planning interior, including a street, is one of the basic units of urban planning and ought to be treated with equal or greater care. It is, after all, on the account of its scale, the environment of human life and man's use of all the named benefits of civilization. It should be, more than anything else, comfortable and build up the well-being of a society.

There is a very high level of complexity of the factors influencing the creation of a street in certain defined form. What is more, the process of its creation is seldom repeatable. The decisions of the provincial and municipal authorities have impact on the process. Then the planners creating spatial law locally and local administration employees responsible for setting road and architectural projects. Another group that has substantial influence on the shape of a street are the road and building designers operating in accordance with the binding local law. Finally, it is influenced by users who choose, consciously or subconsciously, places that they use for various kinds of their activities. Since they are forced to realize some of these activities by location of certain functions (administration, education), the aforementioned participants of the process of creating a city have even greater responsibility to ensure the comfort of usage. Many of the mentioned guidelines could be, like the quoted example of Denmark, included in the local spatial development plan. Other guidelines being too detailed, should be implemented voluntarily by informed designers. In order to make it possible, designers, planners as well as officials responsible for this area of administrative units should be familiar with this kind of rules. This way they could consciously participate in a modern designing process that requires not so much creating buildings or roads as comprehensive creation of places.

\section{Bibliography}

[1] Alexander C.: A Pattern Language: Towns, Buildings, Construction, GWP, Gdańsk 2008, Translation: Kaczanowska A., Maliszewska K., Trzebiatowska M., Lenartowicz K.

[2] Gawlikowski A.: A Street In The City Structure, Warsaw University of Technology, Warsaw 1992.

[3] Gehl J.: Life Between Buildings: Using Public Space, RAM, Cracow 2013, Translation: Urbańska M.

[4] Książek M.: Auxiliary materials for studies in the field of the history of urban planning, Cracow University of Technology, Cracow 1994.

[5] Lynch K.: The Image of the City, Archivolta Michał Stępień, Cracow 2011, Translation: Jeleński T.

[6] Pluta K.: Public Space of the European Cities, Warsaw University of Technology, Warsaw 2012.

[7] Wejchert K.: Elements of Urban Composition, Arkady, Warsaw 1984.

[8] Wicher W.: The Studies in Typology of a Street As an Element of Urban Analysis, Cracow University of Technology, Cracow 1999. 


\section{PRZESTRZEŃ DLA LUDZI WE WSPÓŁCZESNYM MIEŚCIE - JAKIE ROZWIĄZANIA ARCHITEKTONICZNE I URBANISTYCZNE POMAGAJĄ W KSZTAŁTOWANIU FUNKCJONALNEJ I WYGODNEJ ULICY?}

\section{Streszczenie}

Jednymi z podstawowych składników budujących tkankę miejską są ulice. W ścisłym powiązaniu z zabudową definiowały jej układ, bądź były jego pochodną. Ulica od zawsze stanowiła ważny element kształtujący charakter miasta. Nie tylko pełniła funkcję transportową, ale również służyła mieszkańcom jako miejsce spotkań i wymiany handlowej. Szybki rozwój motoryzacji po drugiej wojnie światowej spowodował jednak zachwianie tej równowagi. Coraz więcej przestrzeni ulicy było przeznaczane pod jezdnie i parkingi. Proces ten, $\mathrm{z}$ pewnym opóźnieniem związanym z sytuacją polityczno gospodarczą naszego kraju, przybrał na sile na przełomie XX i XXI w. Państwa Skandynawii, Niemcy i Holandia już w latach sześćdziesiątych zwróciły uwagę na problem dominacji samochodu $\mathrm{w}$ centrach miast prowidujący degradację życia społecznego. Od tamtego czasu podejmowano różnorakie działania celem przywrócenia ulicom cech pozwalających użytkownikom na korzystanie z nich w sposób wygodny i bezpieczny. Dokumentacja przemian rewitalizujących przestrzeni ulicy pozwoliła na wypracowanie pewnych uniwersalnych wskazówek projektowych.

Zgodnie ze współczesnymi trendami urbanistycznymi przy projektowaniu kompleksów zabudowy należy stosować podejście interdyscyplinarne. Poza klasyczną inżynierią należy korzystać również z osiągnięć socjologii, psychologii. Na odbiór ulicy przez jej użytkowników, poza proporcjami poziomych powierzchni, najistotniejszy wpływ mają rozwiązania architektoniczne znajdujących się przy niej budynków. Przykładowymi wytycznymi dla kształtowania poprawnej przestrzeni ulicy jest odpowiednia wysokość budynków, ich położenie względem ulicy czy właściwe rozmieszczenie otworów okiennych i drzwiowych. Celem pracy jest przybliżenie i zestawienie ze sobą źródeł, opisujących wytyczne architektoniczne mające wpływ na tworzenie ulicy przyjaznej dla ludzi. Analizowane teksty dotyczyć będą zarówno rozwiązań architektonicznych, jak i zagadnień z dziedziny psychologii przestrzeni.

Słowa kluczowe: przestrzeń publiczna, projektowanie przestrzeni ulicy, wytyczne architektoniczo urbanistyczne, psychologia przestrzeni

DOI:10.7862/rb.2016.253

Przestano do redakcji: 15.11 .2014 r.

Przyjęto do druku: 20.12.2016 $r$. 
